\title{
PERTANGGUNGJAWABAN PIDANA TERHADAP PELAKU KEKERASAN PENGANJURAN ORGANISASI KEMASYARAKATAN
}

\author{
I Wayan Ajus Sentana Putra, I Made Sepud, Sagung Laksmi Dewi \\ Fakultas Hukum Universitas Warmadewa, Denpasar - Bali, Indonesia
}

\begin{abstract}
Abstrak
Semakin banyaknya kemunculan organisasi baru sebagai akiat dari adanya kekebasan mengeluarkan pendapat, berserikat dan berkumpul memicu timbulnya pengungkapan perbedaan pendapat. Hal itu berwujud aspek demorkasi dalam kehidupan berbangsa dan bernegara. Adanya kebebasan berorganisasi diikuti dengan tindakan anarksis yang dilakukan oleh beberapa organisasi yang merupakan jawaban nyata akiat adanya mekanisme hukum yang tidak berjalan dengan baik. Jadi, daripada tidak berjalan, orgnaisasi lebih baik mengambil tindakan dengan berjalan secara sendiri. Perilaku seperti itu tanpa sadar merupakan tindakan melawan hukum. Masalah yang akan dikaji dalam penelitian ini berkaitan dengan pengaturan tindak pidana penganjuran organisasi kemasyarakatan dan pertanggungjawaban pidana terhadap pelaku kekerasan dalam penganjuran organisasi kemasyarakatan dimaksud. Tipe penelitian ini penelitian hukum normatif dengan pendekatan perundangundangan. Analisis bahan hukum dilakukan dengan metode deskriptif. Pengaturan tindak pidana penganjuran organisasi kemasyarakatan diatur dalam Pasal 55 dan 56 Kitab Undang-Undang Hukum Pidana. Bentuk delik atau unsur penyertaan dalam pasal 5 Kitab Undang-undang Hukum Pidana terdiri dari empat jenis delik, antara lain yaitu: pleger, doenpleger, uitlokker dan medepleger. Pertanggungjawaban pidana pelaku tindak pidana kekerasan penganjuran organisasi kemasyarakatan terwujud dalam aturan yang mewajibkan pembuat dan pelaku sama dijatuhi hukuman; akan tetapi pihak pendukung dapat dihukum lebih ringan dari pembuat, yakni dikurangi dengan sepertiga dari maksimum pidana kejahatan yang diancam dengan hukuman mati atau penjara seumur hidup, asisten dihukum maksimal 15 tahun penjara.
\end{abstract}

Kata Kunci: Kekerasan; Ormas; Pidana; Penganjuran

\begin{abstract}
The increasing number of new organizations appearing as a result of the freedom of expression, association and assembly, triggers the expression of dissent. It manifests aspects of democracy in the life of the nation and state. Freedom of association followed by anarchist actions taken by several organizations serves as a real answer due to the existence of legal mechanisms that do not work well. So, rather than not working, the organization is better to take action by walking alone. Such behavior is unconsciously an act against the law. The problem examined in this study relates to the regulation of criminal acts advocating social organizations and criminal liability against perpetrators of violence in the advocacy of such social organizations. This type of research is normative legal research with a statutory approach. Analysis of legal material is done by descriptive method. The regulation of criminal acts advocating social organizations set forth in Articles 55 and 56 of the Criminal Code. The form of offense or the element of inclusion in article 5 of the Criminal Law Code consists of four types of offenses, including: pleger, doenpleger, uitlokker and mediepleger. The criminal liability of perpetrators of violent acts advocated by social organizations is manifested in a rule requiring the makers and perpetrators to be equally punished; however, supporters can be sentenced lighter than the maker, which is reduced by one third of the maximum criminal offense threatened with capital punishment or life imprisonment, the assistant is sentenced to a maximum of 15 years in prison.
\end{abstract}

Keywords: Violence; Civil Society Organization; Criminal; Advocacy

\section{PENDAHULUAN}

Proses pembangunan bangsa diawali sejak adanya rasa sadar dari rakyat baik individu maupun berkelompok yang bertujuan dan mempunyai landasan yang sama. Organisasi masyarakat (Ormas) dibangun karena adanya cita-cita membangun kesadaran berkelompok dengan tujuan untuk 
kepentingan bersama guna menyelesaikan permasalahan umum yang terjadi (Wibowo \& Harefa, 2015; Kurniawan, 2018). Bentuk organisasi yang digunakan ini memiliki banyak perbedaan dengan partai politik.

Ormas didirikan oleh sekelompok masyarakat berdasar persamaan kegiatan umum, profesi, tujuan, dan fungsi antara lain: agama, pendidikan, budaya, ekonomi, hukum, dan sebagainya (Hardiyanto, 2018). Ormas sebagai peran masyarakat dalam menjalankan pembangunan untuk kehidupan yang adil dan sejahtera. Eksistensi organisasi masyarakat sipil di Indonesia telah terbentuk sejak awal abad ini dan memiliki posisi paling strategis untuk proses nasional Indonesia.

Beberapa ormas sudah melaksanakan aktivitas positif melibatkan masyarakat, seperti melindungi lingkungan, seperti Forum untuk Lingkungan (Walhi), memberi bantuan masyarakat dalam lembaga bantuan hukum $(\mathrm{LBH})$ dan di area lain dengan untuk memainkan peran di mana kegiatan sosial dilakukan secara damai dengan memberdayakan masyarakat. Di sisi lain, ada juga organisasi yang melakukan tindakan melawan hukum. Keberadaan organisasi untuk beberapa kalangan adalah baik, karena itu tidak hanya kendaraan untuk kegiatan, tetapi juga sarana untuk menyalurkan keinginan dan pikiran, baik dalam tingkat internal organisasi, dan dalam konteks penyaluran pikiran dan opini dalam kehidupan Negara (Situmeang dkk., 2012).

Tanggung jawab untuk menerapkan keamanan publik adalah tanggung jawab semua aspek masyarakat, baik aparatur negara dan masyarakat secara menyeluruh (Nuriyanto, 2014). Gangguan adalah produk dari komunitas itu sendiri. Berhasil tidaknya organisasi ditentukan oleh kualitas SDM yang dimiliki, etika, kepribadian anggota organisasi, dengan lain perkataan: sumber daya manusia adalah sumber organisasi (Bukit dkk., 2017). Jika terdapat organisasi sosial yang bertentangan dengan prinsip- prinsip negara Pancasila, maka disitulah pemerintah berperan guna melakukan pembinaan melalui kebijakan kemitraan adalah bahwa semua aspek masyarakat berperan dalam menjaga agar lingkungan merkea tetap aman dan tertib.

Beragai kajian tentang pertanggungjawaban pidana atas berbagai tindakan kejahatan dalam satu dekade memiliki fokus pada bentuk kejahatan, perlindungan hukum dan bentuk pertanggungjawaban pada ranah hukum. Kekerasan merupakan seuah bentuk kejahatan yang dapat dijatuhi hukuman pidana berdasarkan Kitab Undang-Undang Hukum Pidana (KUHP) dan beberapa peraturan di luar KUHP (Anjari, 2014). Perdangan illegal juga merupakan salah satu bentuk tindak pidana kejahatan, tetapi peraturan perundang-undangn yang dapat digunakan untuk melindungi korban dan menjatuhkan sanksi kepada pelaku ialah No. 5 Tahun 1990 Undang-Undang Konservasi Sumber Daya Alam Hayati dan Ekosistemnya (Saputra, 2016). Terkait dengan perlindungan korban kekerasan seksual dan pertanggungjawabannya ditentukan dalam Undang-Undang No. 36 Tahun 2009 tentang Kesehatan, Peraturan No 64 Tahun 2014 tentang Kesehatan Reproduktif (Ramada, 2017) Kekerasan terhadap perempuan juga merupakan bentuk kejahatan yang dilarang dalam peraturan perundang-undangan Republik Indonesia. Kajian penelitian sebelumnya terhadap objek ini mengungkap mengenai tindakan kejahatan tersebut diatur dalam Undang-Undang Nomor 23 Tahun 2004 tentang Penghapusan Kekerasan dalam Rumah Tangga (Sari \& Purwanti, 2018). Kemudian, pertanggungjawaban pidana perusahaan di Indonesia juga diatur dalam KUHP dan KUHAP dan di luar itu (Maradona, 2018).

Penelitian ini dilakukan untuk menyoroti dua permasalahan: (1) Bagaimanakah pengaturan tindak pidana penganjuran organisasi kemasyarakatan? (2) Bagaimanakah pertanggungjawaban pidana terhadap pelaku kekerasan penganjuran organisasi kemasyarakatan? Melihat sering terjadinya kasus tindak pidana penganjuran organisasi kemasyarakatan memicu pentingnya telaah untuk mengungkap bentuk-bentuk peraturan perundang-undangan yang mengatur hal tersebut sekaligus untuk menguraikan bentuk pertanggungjawaan bagi pelaku tindakan tersebut.

\section{METODE PENELITIAN}

Penelitian normatif adalah tipe penelitian yang digunakan dengan pendekatan peraturan perundangan, yaitu hukum diasumsikan sebagai aturan hukum sebagai acuan bertingkah laku yang pantas (Amiruddin \& Asikin, 2012), pendekatan konseptual (Conseptual Approach) dan pendekatan sosial kemasyarakatan (Comumunity Based) (Marzuki, 2006). Bahan hukum primer, sekunder dan tersier digunakan sebagai data penelitian ini. Studi dokumentasi digunakan untuk teknik pengumpulan data (Suratman, 2009). Data dikumpulkan melalui wawancara dengan beberapa anggota organisasi, baik yang pelaku maupun korban. Selain itu, hasil-hasil penelitian dan literature 
yang berkaitan dikumpulkan dan dibaca untuk bandingkan dengan pembahasan dalam penelitian ini. Peraturan Perundang-undangan, KUHP dan KUHAP jug abaca terutama yang terkait dengan organisasi kemasyarakatan. Data dianalisis secara kualitatif dan disajikan secara deskriptif. Setelah data dianalisis, disajikan dengan memberikan pembahasan. Langkah terakhir ialah menarik simpulan dalam kaitan dengan hasil penelitian yang berpatokan pada rumusan permasalahan.

\section{HASIL PENELITIAN DAN PEMBAHASAN}

\section{Pengaturan Tindak Pidana Kekerasan Penganjuran Ormas}

Tindak pidana kerap terlaksana karena adanya keterlibatan orang lain atau bersama-sama bersama sejumlah besar pelaku (massa). Ini sesuai dan membutuhkan penyelidikan ke dalam relasi kedua belah pihak untuk membuat terang dan jelas bahwa pertanggungjawaban pidana atau pertanggungjawaban otoritas penegak hukum pada pihak-pihak dilihatkan secara langsung atau tidak langsung bertanggung jawab.

Bentuk-bentuk penyertaan terdapat dalam Pasal 55 ayat (1) Kitab Undang-Undang Hukum Pidana yang menyatakan dapat dipidana sebagai pembuat (dader) dari suatu perbuatan atau tindak pidana yang berbunyi:

Ayat (1) Mereka yang melakukan, yang menyuruh lakukan dan turut serta melakukan yang titerjemahkan diam bahasa belanda menjadi zin die net feit plegen, doen plegen en medeplegen.

Ayat (2) Mereka yang dengan memberi atau menjanjikan sesuatu, dengan menyalahgunakan kekuasaan atau martabat, dengan kekerasan, ancaman atau penipuan, atau dengan memberikan peluang, sarana atau informasi, dengan sengaja mendorong orang lain untuk melakukan tindakan kriminal atau zij die het feit uitloken.

Adapun bentuk dari pembantuan tertera pada Pasal 56 Kitab Undang-Undang Hukum Pidanan yang menentukan bahwa dapat di pidana sebagai medeplictge atau pembantu suatu kejahatan adalah berbunyi :

Ayat (1) Mereka yang dengan sengaja memberi bantuan pada waktu kejahatan sedang di lakukan.

Ayat (2) Mereka yang sengaja memberi peluang, fasilitas atau informasi untuk melaksanakan kejahatan.

Ketentuan Pasal 55 dan Pasal 56 Kitab Undang-Undang Hukum Pidana ini, dapat diambil kesimpulan bahw yang dimaksud dengan istilah penyertaan adalah apabila ikut sertanya seseorang atau lebih pada saat orang lain melakukan suatu kejahatan atau tindak pidana (Wirjono, 2009). Walaupun ciri- ciri penyertaan atau deelneming pada suatu strafbaar feit atau perbuatan pidana itu ada, namun jika didalam delik tersangka terlibat lebih dari satu orang atau beberapa orang, akan tetapi tidak setiap orang yang bersangkutan yang turut serta dalam tindak atau perbuatan pidana tersebut bisa dikatakan menjadi seorang bisa diberi pidana.

Perbuatan pidana atau tindak pidana yang dilakukan oleh beberapa orang atau kelompok secara massal atau yang dilkukan oleh lebih dari satu orang, didalam hukum pidana di Indonesia mengenal istilah tersebut dengan delik atau unsur penyertaan yang temasuk dalam bentuk khusus dari hukum pidana di Indonesia. Adapun bentuk dari delik atau unsur penyertaan dalam Pasal 5 KUHP terdapat 4 delik penyertaan antara lain (Schaffmeister dkk., 2015):

1. Pleger atau yang melakukan perbuatan pidana ialah satu orang pada dasarnya adalah pribadi (individu) yang jelas melakukan tindakan sempurna yang memenuhi semua elemen perumusan pelanggaran dan yang dalam kasus ini melakukan kejahatan secara sendiri.

2. Doenpleger atau yang menyuruh melakukan perbuatan atau tindak pidana adalah seorang yang mempergunakan seorang perantara atau orang lain yang tidak dapat di pidana untuk mencapai tujuannya. Hal ini di karenakan bahwa orang yang di suruh memiliki ketidak mampuan dalam bertanggung jawab untuk itu adanya alasan pemaaf. Dalam hal ini dapat dikatakan bahwa pihak 
yang menyuruh atau actor intellectual dan pihak yang disuruh sebagai actor material serta peran sipembujuk bersifat limitatif.

3. Uitlokker atau yang menganjurkan perbuatan atau tindak pidana dalah seorang yang membujuk atau menganjurkan untuk dapat jalan pada orang lain untuk rencana-rencana sendiri, agar orang lain atau seseorang melakukan perbuatan pidana. Berkaitan dengan hal ini si pembujuk menggunakan sarana-sarana pembujukan seperti: janji-janji, pemberian- pemberian, kekerasan, penyalahgunaan kekuasaan, tipu daya, ancaman, sarana- sarana, keterangan-keterangan atau kesempatan-kesempatan. Kedudukan pihak penganjur atau si penganjur dalam hal ini adalah sebagai actor intellectualist dan yang dianjurkan atau si pelaku sebagai actor materialis, untuk itu peran si pembujuk tidak bersifat limitatif.

4. Medepleger atau yang turut serta melakukan perbuatan pidana adalah seseorang yang ikut serta memberi ide melalui komunikasi bersama orang lain dimana menurut kesepakatan itu mereka sama-sama melakukan delik pidana atau perbuatan pidana.

\section{Pertanggungjawaban Pidana Pelaku Tindak Pidana Kekerasan Penganjuran Organisasi Kemasyarakatan}

Kekerasan membentuk firut yang khas dalam dokumen studi kejahatan dan bila dikaitkan dengan masalah kejahatan, maka kekerasan menjadi faktor yang melengkapi bentuk kejahatan itu sendiri. Semakin besar frekuensi kejahatan yang diikuti oleh masyarakat akan menjadi penting dan keseriusan jenis kejahatan ini. Sehingga untuk selanjutnya perbedaan persepsi publik terhadap model kejahatan ini telah terbentuk.

Dalam kamus bahasa Indonesia, kekerasan didefinisikan sebagai karakter, sifatnya keras, merupakan tindakan seseorang mengakibatkan orang lain menjadi cidera dan meninggal dunia atau menyebabkan kerusakan fisik atau harta benda kepada orang lain, atau ada paksaan. Menurut pernyataan ini, kekerasan adalah bentuk tindakan teruju pada fisik berakibat cedera, cacat, sakit, atau penderitaan bagi orang lain. Unsur yang membutuhkan perhatian ialah bentuk paksaan atau ketidaksabaran atau tidak ada kesepakatan dari pihak lain yang terluka.

Kekerasan terletak pada benda-benda fisik dan psikologis, hanya saja penekanannya adalah pada bentuk fisik serangan seperti cedera atau cedera, cacat atau kelainan pada tubuh fisik tertentu (Fakih, 1996). Naum, dapat juga terjadi bahwa itu adalah kekerasan fisik, tetapi memiliki efek berkelanjutan pada aspek psikologis. Parahnya penderitaan psikologis juga dapat dialami oleh korban kekerasan fisik, seperti stres yang kemudian akan diikuti dengan aksi membunuh diri. Pernyataan yang lahir dan umumnya berlaku, segala bentuk kekerasan adalah bentuk pelanggaran hak asasi manusia, yang berarti bahwa tindakan kekerasan di lingkungan maysarakat misalnya, mengakibatkan hilangnya orang lain.

Tanggung jawab pidana mengarah pada hukuman bagi pelaku jika ia telah melakukan kejahatan dan memenuhi unsur-unsur yang ditentukan oleh hukum (Kertanegara, 1954). Dilihat dari saat tindakan suatu tindakan jika itu melanggar hukum. Unsur mampu bertanggung jawab, antara lain:

1) Keadaan jiwanya;

a) Tidak mengalami gangguan sakit yang terus menerus atau sementara (temporary);

b) Tidak mengalami cacat dalam pertumbuhan (gagu, idiot, imbisil, dsb);

c) Tidak ada ganguan karena keterkejutan, hipnotis, kemarahan yang terlalu penuh, pengaruh yang tidak disadari, demam.

2) Kemampuan jiwanya ;

a) Bisa menyadari hakekat tindakanya;

b) Bisa menunjukkan keinginannya untuk tindakan ini

c) Dapat mengetahui ketercelaan dari tindakan tersebut.

Tanggung jawab didasari keadaan dan kemampuan jiwa tidak keadaan dan kemampuan pikiran dari seseorang. Komponen dan subjek tanggung jawab pidana dijelaskan di bawah ini: 
a. Unsur-unsur dalam pertanggungjawaban pidana

Seseorang atau pelaku kejahatan tidak memiliki tanggung jawab pidana atau didakwa melakukan tindak pidana jika ia tidak melakukan tindak pidana dan tindakan pidana tersebut harus melanggar aturan, tetapi bahkan jika ia melakukan tindak pidana, ini tidak se lalu dapat dikutuk. Seseorang yang melakukan kejahatan hanya dihukum jika dia terbukti secarahukum dan diyakinkan untuk berbuat salah. Menurut Saleh (1983), tidak masuk akal untuk meminta tersangka bertanggung jawab atas tindakannya jika tindakan itu sendiri tidak melanggar hukum, sehingga dapat juga dikatakan bahwa pertama-tama semestinya terdapat kepastian perihal tindak pidana, dan selanjutnya seluruh elemen kesalahan wajib juga terkait dengan tindak pidana yang dibuatnya, yaitu untukpada kesalahan yang mengarah ke hukuman terdakwa, maka dia harus:

1) Melakukan perbuatan pidana;

2) Mampu bertanggungjawab;

3) Dengan kesengajaan atau kealpaan, dan

4) Tidak adanya alasan pemaaf.

Istilah "pidana" merupakan istilah yang lebih khusus, yaitu menunjukkan sanksi dalam hukum pidana. Selain itu istilah "pidana" merupakan istilah yang khusus dalam hukum pidana menggantikan istilah hukuman, perlu untuk membatasi konsep atau makna sentral yang mungkin memiliki ciri khas. Saleh (1983) menyatakan "Pidana adalah reaksi atas delik, dan ini berwujud suatu nestapa yang dengan sengaja ditimpakan negara kepada pembuat delik itu".

Berdasarkan UU No. 17 Tahun 2013 tentang Organisasi Sosial diatur mengenai pertanggungjawaban pidana atas tindakan kriminal anggota organisasi sosial atau orang yang mengadvokasi organisasi masyarakat sipil, sebuah aturan yang mengatur semua aktivitas dan acara organisasi sosial demi mencapai negara kesatuan Republik Indonesia dijadikan contoh bagi masyarakat dalam bertindak dalam masyarakat umum. Untuk alasan ini, dengan adanya peraturan tersebut, setiap anggota organisasi massa memiliki hak dan kewajiban dalam melaksanakan tugasnya sebagai anggota yang berjuang untuk negara dan masyarakat.

Dalam praktiknya, ada berbagai organisasi komunitas yang melakukan tindakan melawan perundangan dan bahkan beberapa anggota organisasi berbentuk kelompok yang sebenarnya memiliki visi selain visi asli organisasi, sehingga masing-masing dari mereka pergi mencari anggota lain untuk pemenuhan tujuan mereka untuk kepentingan sendiri. Terkadang, tedapat anggota ormas mengambil perbuatan anarkis ketika berdemonstrasi atau tindakan yang menyebabkan tindakan kriminal yang menyebabkan korban, kerusakan lingkungan dan menyebabkan ruginya negara.

Terkait tanggung jawab pidana bagi pelaku kekerasan, aktor advokasi dapat dikategorikan sebagai perintah atau insentif untuk melakukan pemicu, setidaknya ada lebih dari satu orang, yang secara individual dapat berupa perkumpulan orang-orang atau dinamakan kelompok intelektual. Aktor dan seseorang yang direkomendasikan atau sering direkomendasikan. disebut actor materialistic. Advokasi berbentuk aktor intelektual yang mendorong orang lain atau pelaku materialistis tindak pidana. Pemrakarsa adalah orang yang memuja atau mendorong orang lain untuk melakukan suatu tindakan atau tindakan kriminal, menggerakkan orang lain untuk memenuhi apa yang ia usulkan. Hal ini terjadi karena dipengaruhi atau dirayu oleh upaya atau metode dan upaya para pendukung untuk melakukan sebagaimana diatur dalam Pasal 55 Ayat (1) Buku II Hukum Pidana.

\section{SIMPULAN}

Pengaturan tindak pidana penganjuran organisasi kemasyarakatan tertuang dalam KUHP pada Pasal 55,56 . bentuk dari delik atau unsur penyertaan dalam pasal 5-nya terdapat 4 delik penyertaan antara lain: pleger, Doenpleger dan Uitlokker dan Medepleger.

Pertanggungjawaban Pidana terhadap pelaku tindak pidana kekerasan penganjuran organisasi kemasyarakatan terwujud dalam situasi dimana pembuat dan pelaku keseluruhan dipidana. Namun pihak rekannya diberikan pidana lebih ringan dibanding pembuatnya, dikurangi 1/3 dari pengancaman terlama pidana yang dilakukan seperti yang ditemukan pada Pasal 57 Ayat (1) Kitab Undang- Undang Hukum Pidana, jikalau kejahatan diancam pidana mati atau pidana seumur hidup, rekannya dipidana kurungan paling lama 15 tahun. 


\section{DAFTAR PUSTAKA}

Amiruddin, \& Asikin, Z. (2012). Pengantar Metode Penelitian Hukum. Rajawali Pers.

Anjari, W. (2014). Fenomena Kekerasan sebagai Bentuk Kejahatan (Violence). E-Journal Widya Yustisia, 1(1), 42-51. https://media.neliti.com/media/publications/246968-fenomena-kekerasansebagai-bentuk-kejaha-60c284aa.pdf

Bukit, B., Malusa, T., \& Rahmat, A. (2017). Pengembangan Sumer Daya Manusia (1st ed.). Zahir Pulishing. file:///C:/Users/Smile/Downloads/manajemen sumber daya manusia ( PDFDrive.com ) .pdf

Fakih, M. (1996). Posisi Kaum Perempuan Dalam Islam: Tinjauan Dari Analisis Gender. Tarjih, 1, 22-37.

Hardiyanto, I. (2018). Pengaturan Pendirian dan Pembubaran Organisasi Masyarakat pada Masa Orde Baru dan Setelah Reformasi [Universitas Islam Indonesia]. https://doi.org/10.1017/CBO9781107415324.004

Kertanegara, S. (1954). Catatan Kuliah Hukum Pidana 11 Mahasiswa PTIK Angkatan V.

Kurniawan, M. B. (2018). Konstitusionalitas Perppu Nomor 2 Tahun 2017 tentang Ormas Ditinjau dari UUD 1945. Jurnal Konstitusi, 15(3), 455. https://doi.org/10.31078/jk1531

Maradona. (2018). Corporate Criminal Liability in Indonesia: Regulation, Implementation and Comparison with the Netherlands. Erasmus University Rotterdam.

Marzuki, P. M. (2006). Penelitian Hukum. Predana Media.

Nuriyanto, N. (2014). Penyelenggaraan Pelayanan Publik Di Indonesia, Sudahkah Berlandaskan Konsep "Welfare State"? Jurnal Konstitusi, 11(3), 428-453.

Ramada, D. P. (2017). Reality of Protection for Sexual Violence Victims: Comprehensive Protection Analysis for Sexual Violence Victims. IJCLS (Indonesian Journal of Criminal Law Studies), 2(2), 168-183. https://doi.org/10.15294/ijcls.v2i2.12324

Saleh, R. (1983). Stelsel Pidana Indonesia. Aksara Baru.

Saputra, T. (2016). Pertanggungjawaban Pidana terhadap Pelaku Tindak Pidana Perdagangan Ilegal Satwa Liar yang Dilindungi berdasarkan Undang-Undang Nomor 5 Tahun 1990 Tentang Konservasi Sumber Daya Alam Hayati dan Ekosistemnya di Wilayah Hukum Ditreskrimsus Polda Riau. JOM Fakultas Hukum Universitas Riau, III(5), 1-12.

Sari, A. A., \& Purwanti, A. (2018). Penegakan Hukum Tindak Pidana Kekerasan Terhadap Perempuan Di Kota Demak. Masalah-Masalah Hukum, 47(3), 317. https://doi.org/10.14710/mmh.47.3.2018.317-337

Schaffmeister, D., Keijzer, N., \& Sutorius, E. P. . (2015). Hukum Pidana. Liberty.

Situmeang, I., Lubis, D. P., \& Saleh, A. (2012). Bentuk Komunikasi Organisasi Melalui Kegiatan Tanggungjawab Sosial Perusahaan Untuk Pemberdayaan Masyarakat. Jurnal Komunikasi Pembangunan, 10(1), 27-46.

Suratman. (2009). Metode Penelitian Hukum. Alfabeta.

Wibowo, C., \& Harefa, H. (2015). Urgensi Pengawasan Organisasi Kemasyarakatan oleh Pemerintah. Jurnal Bina Praja, 07(01), 01-19. https://doi.org/10.21787/jbp.07.2015.01-19

Wirjono, P. (2009). Asas-Asas Hukum Pidana di Indonesia. Ereco. 